(7)

\title{
Analysis of Trade Competitiveness of Pakistan Cereal Products in Global Perspective
}

\author{
${ }^{\mathrm{a}}$ Muhammad Shahid Maqbool, ${ }^{\mathrm{b}}$ Tahir Mahmood, 'Saddam Hussain, ${ }^{\mathrm{c}}$ Muhammad Ashraf \\ ${ }^{a}$ Lecturer Department of Economics, Government Post Graduate College Gojra, Pakistan \\ ${ }^{\mathrm{b}}$ Associate Professor, Department of Economics and Business Management, University of Veterinary \& Animal \\ Sciences, Lahore \\ ${ }^{\mathrm{c}}$ M. Phil. Scholar of Economics, Bahauddin Zakariya University, Multan
}

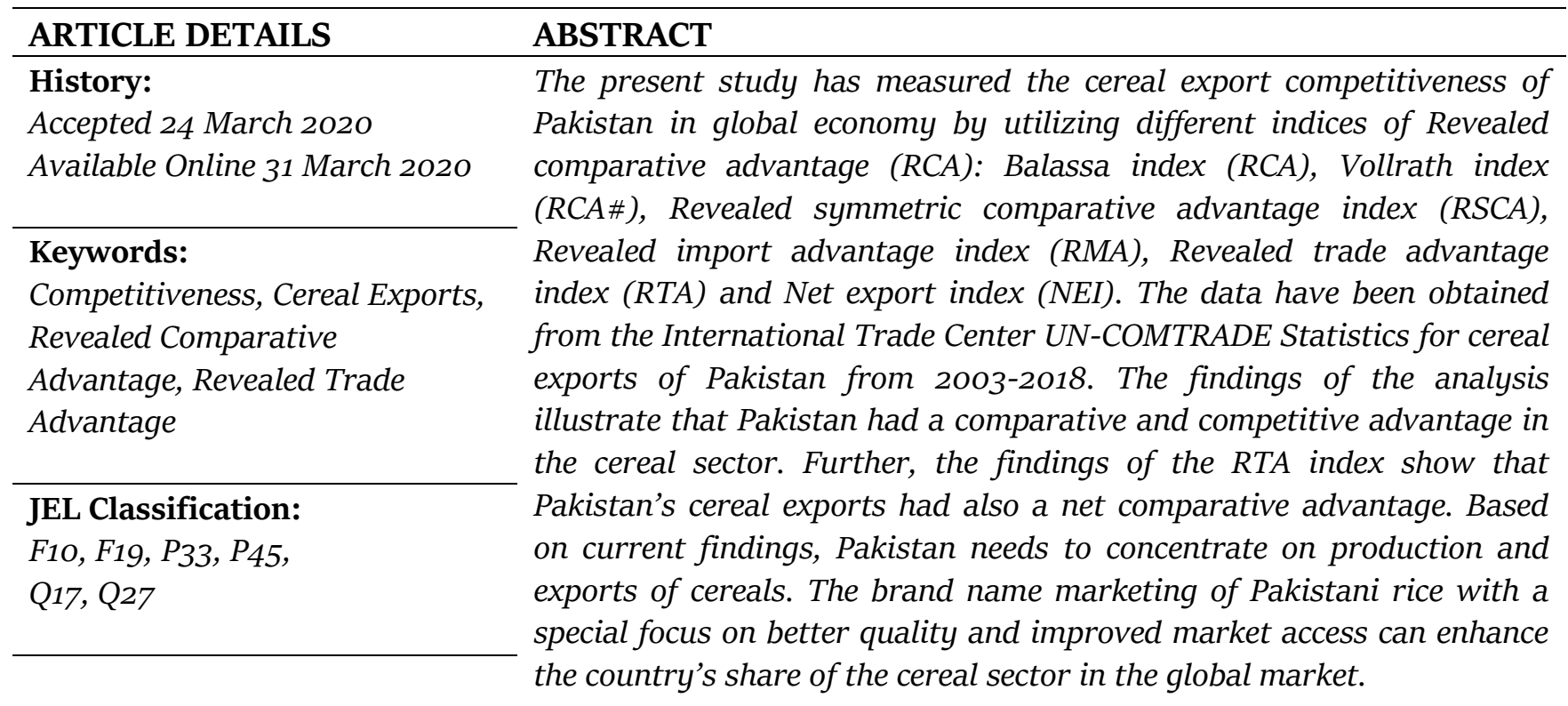

DOI: $10.47067 /$ reads.v6i1.187

(C) 2020 The authors. Published by SPCRD Global Publishing. This is an open access article under the Creative Commons Attribution-

NonCommercial 4.0

Corresponding author's email address: shahidmakbool@gmail.com

\section{Introduction}

Cereals are the most important food grains and a rich source of minerals, vitamins carbohydrates and protein. Wheat, rice, maize, barley, oats, and sorghum are the most grown cereal crops in the world. These crops are grown in larger quantities to meet the food requirements of a huge share of the world population. The cereal foods provide 50 percent of calories and 46 percent protein in an average diet as reported by Agricultural and Food organization. Wheat and rice are the most vital crops covering over nearly 52 percent of the world cereal production. FAO estimates that wheat, rice and maize account for more than 75 percent of all grain production in the world. In some developing economies, the grains in the form of rice, wheat or maize constitute the livelihood of the majority. In developed countries, cereal consumption is moderate and varied but still considerable. In addition, onethird population of the world takes food from wheat (Zhou, 2009 and Janvry, 2010). The total annual 
cereal production is about 2500 million tons in the world (Tonini and Cabrera, 2011).FAO's forecast for 2019 world cereal production is pegged at an all- time high of 2714 million tons and it is almost 57 million tons higher than the reduced outturn in 2018. World cereal utilization in $2019-20$ is forecast at 2709 million tons and it is recorded of around 21 million tons higher than in 2018-19 utilization. On the other hand, world trade in cereal in $2019-20$ is forecast at 416 million tons as compared to 411.6 million tons in 2018-19 level and it is 4.5 million tons higher.

In developed economies, cereal crops are machine harvested while in developing economies, a variety of harvesting methods are used in cereal cultivation depending on the labor cost, from small combines to hand tools such as cradle (Harwood, 2019). Crop production systems have changed rapidly over the past century and have resulted in considerable increased crop yields, but have also produced undesirable environmental side effects (Hobbs et al., 2007). Factors such as the green revolution have led to impressive progress in increasing cereal yield over the last few decades. The progress is not equal across all regions. The continued progress depends on maintaining agriculture and education. The cultivation of cereals varies widely in different countries and depends partly on the development of the economy. The production of cereals also heavily depends on the quality of soil along with rainfall, irrigation and production techniques (Rockstrom et al., 2007).

Table 1 Export and Import growth of Cereal products of Pakistan in the world from 2003-18 (Billions US\$)

\begin{tabular}{|l|l|l|l|l|l|l|l|l|}
\hline Years & CREOP & $\begin{array}{l}\text { Percentage } \\
\text { change }\end{array}$ & CREOW & $\begin{array}{l}\text { Percentage } \\
\text { change }\end{array}$ & TEP & $\begin{array}{l}\text { Percentage } \\
\text { change }\end{array}$ & CRIP & $\begin{array}{l}\text { Percentage } \\
\text { change }\end{array}$ \\
\hline 2003 & O.67 & & 39.24 & & 16.05 & & O.01 & \\
\hline 2004 & 0.63 & -5.02 & 45.30 & 15.43 & 12.59 & -21.59 & 0.03 & 141.62 \\
\hline 2005 & 1.10 & 73.72 & 44.42 & -1.93 & 16.05 & 27.53 & 0.16 & 361.56 \\
\hline 2006 & 1.15 & 4.70 & 50.00 & 12.56 & 16.93 & 5.50 & 0.13 & -18.13 \\
\hline 2007 & 1.24 & 7.97 & 72.56 & 45.10 & 17.84 & 5.35 & 0.11 & -16.02 \\
\hline 2008 & 2.51 & 101.58 & 104.68 & 44.27 & 20.28 & 13.68 & 1.69 & 1423.45 \\
\hline 2009 & 1.82 & -27.30 & 78.49 & -25.01 & 17.55 & -13.43 & 0.33 & -80.43 \\
\hline 2010 & 2.28 & 25.03 & 84.69 & 7.89 & 21.41 & 21.98 & 0.07 & -77.87 \\
\hline 2011 & 2.81 & 23.15 & 117.49 & 38.74 & 25.34 & 18.36 & 0.10 & 31.67 \\
\hline 2012 & 2.06 & -26.59 & 120.51 & 2.56 & 24.61 & -2.88 & 0.09 & -4.76 \\
\hline 2013 & 2.18 & 5.83 & 123.77 & 2.71 & 25.12 & 2.06 & 0.23 & 153.93 \\
\hline 2014 & 2.21 & 1.39 & 120.42 & -2.71 & 24.72 & -1.59 & 0.29 & 22.80 \\
\hline 2015 & 1.94 & -12.17 & 104.15 & -13.51 & 22.09 & -10.65 & 0.10 & -63.90 \\
\hline 2016 & 1.72 & -11.59 & 96.67 & -7.19 & 20.53 & -7.04 & 0.15 & 42.02 \\
\hline 2017 & 1.75 & 2.01 & 103.79 & 7.37 & 21.88 & 6.55 & 0.09 & -37.02 \\
\hline 2018 & 2.33 & 32.78 & 110.13 & 6.10 & 23.63 & 8.01 & 0.13 & 39.87 \\
\hline
\end{tabular}

Sources; Authors own calculations, Where CREOP $=$ Cereal export of Pakistan, CREOW $=$ Cereal export of World, TEP $=$ Total export of Pakistan, CRIP= Cereal Import of Pakistan

Table 1 explains the import and export growth in the cereal sector of Pakistan from 2003-2018 to the world economies. An increasing and decreasing trend of export and import was seen during the selected time period. The growth of cereal export, in 2008, increased by $101.58 \%$ due to the increase in the production of rice, while in the same year the wheat import witnessed a massive increase from Argentina. Major cereals produced in Pakistan include wheat, rice, maize, and barley. The aggregate cereal output is estimated at approximately average level of 42 million metric tons in 2018 that is 6 percent below the record level in 2017. The cereal production for Pakistan was 44.1 million metric tons in 2017. The cereal production grew significantly from 10.8 million to 44.1 million metric tons increased 
at a rate that reached a maximum of 17.9 percent in 1986 and decreased to 3.63 percent in 2017. The cereal production remained in the range of 10.8 - 44.1(million metric tons) and showing fluctuation in the production during the period. The cereal exports consist mostly of rice and wheat. In 2019, rice export is forecast at 3.9 million tons close to the previous five year average, while wheat exports in 2019 are forecast to increase from last year's average level reflect strong sale in recent period. Between May and October 2018 cumulative wheat export from Pakistan were estimated at 8500oo tons considerably higher than previous five year average

The WTO Agreement on Agriculture (AOA) is the first step toward establishing the "fair and market oriented agriculture trading system and rules regarding market access, domestic support and export subsidies. All the domestic support to the farmers is subject to the specific rules of WTO defined in AOA. It was implemented over a six year period for developed countries and for developing economies within a ten year period.This agreement was launched in DOHA in 1995 and is ongoing. Pakistan has a great potential to produce and exports its agriculture products. The government of Pakistan initiated the strategic trade policy framework (STPF) 2015-18 aiming at export promotion by enhancing global trade competitiveness and innovations (GOP, 2016). The effective utilization of natural and financial resources can help Pakistan to reap the benefits of comparative and competitive advantage (Sultana et al., 2009). Pakistan always not in a position to give subsidies to its farmers in any shape but in exceptional circumstance, provide subsidies. Pakistan has comparative advantage in the important crops like wheat, rice, cotton and sugarcane crops but due to lack of infrastructure and modern facilities, Pakistan is not in a position to export these crops. In this context, Pakistan local farmers are unable to export their agricultural product because the government of Pakistan does not give any subsidies to its local farmers.

On the other hand, the developed countries are giving subsidies to their farmers to enhance their exports. It has created artificial competitive edge to developed countries which hurts the export prospects for Pakistan economy. A favorable environment with suitable climatic conditions can increase the comparative advantage of Pakistan in cereal production and exports. Pakistan needs to redesign its agricultural strategy and trade policy in the wake of WTO agreements. The effective utilization of natural and financial resources can help Pakistan to reap the benefits of comparative and competitive advantage (Sultana et al., 2009). The aims of the present study is to measure the export competitiveness of the cereal sector of Pakistan in the global market by using a set of revealed comparative advantage indices. These indices proffer valuable measures to analyze CA on the bases of actual trade performance. The present study also utilized relative import advantage index to measure the comparative advantage in the cereal imports as Pakistan also import cereal from other economies. Moreover, this study employed relative trade advantage index to measure net trade advantage in the cereal sector. The current analysis will be beneficial to boost the export competitiveness of cereal as the global markets have transformed into far more competitive than ever before. As no valuable research employing these indices has been carried out yet to measure the cereal export competitiveness of Pakistan, and it will be highly valuable and dynamic for the future prospective also.

\section{Review of Literature}

The method of Revealed Comparative Advantage has been utilized by a number of studies to measure the competitiveness of the economies, and Balassa and Marcus (1989) also employed the RCA index to examine the competitiveness of USA and Japan during 1967-1983. Haddad (2000) employed intra-industry index and RCA to measure the export competitiveness of the Middle East and North Africa in the global market from 1985-1997. The findings of the analysis illustrated that the diversifications in the selected exports were nominal and export competitiveness was not observed in 
the absence of these diversifications. The RCA index was also employed by Mehmood (20oo) to examine the competitiveness and specialization in the exports of Malaysia. The results of the study illustrate that competition among the ASEAN countries was affected by free trade agreements and new producers. The method of RCA was utilized by Benders and $\mathrm{Li}$ (2002) to measure the export competitiveness of Latin American and Asian economies from 1981-1997. The findings of the analysis illustrated that the CA of East Asian economies decreased as compared to selected countries. Thorne (2005) measured the export competitiveness of cereal production in the EU member countries by utilizing the data from Farm Accountancy Data Network (FADN) for the period 1996-20oo. The study applied profitability as a measure of competitive performance while the value of output, cost of production and partial productivity indicators was investigated as sources of competitive performance. The competitiveness of the UK cereal sector was examined by Thelwell and Ritson (2006) and concluded that the supply chains in the economy of the UK generally have a better size structure providing opportunities for economies. Blazejczyk-Majka and Boczar (2011) investigated the space between oil crops and cereals in terms of significance in the world from 1961-2007. The findings illustrate no competition for space between both groups of crops in the selected period. Voicilas (2014) analyzed the cereal market of Romania at the regional and national levels during 1990-2012. The results indicated that Romania is less developed and incompetent in the cereal sector. The export competitiveness of ex-Yugoslavian countries including Bosnia and Herzegovina, Croatia, Macedonia, Montenegro, Serbia and Sloveniawas examined by Muamer and Snjezana (2015) by employing Michaely index, RCA index and Herfindahl-Hirschman concentration indices. The findings illustrated that the export competitiveness of selected economies is generally unsatisfactory during 2006-2013. Xu et al. (2018) examined the role of China and India in textile competition in the US market from 2000-16 by utilizing competition index. The results showed that both India and China had a high comparative advantage in the import trade of clothing and textile raw materials in the USA. The relationship between comparative advantage and increasing return to scale was examined by Pflüger and Tabuchi (2019) by utilizing a simple integrated Ricardo-Marshall framework. Different indices of revealed comparative advantage were employed by Kim (2019) to measure the competitiveness of Indian clothing and textile sector in the USA. The results highlighted that India had a CA in the clothing and textile sector during 1991-2017.

As far as Pakistan is concerned Sharif et al. (2015) employed the RCA method to measure the export performance of cereals from Pakistan during the period 2007-2013. The findings of the analysis indicate that Pakistan had a CA in the cereal sector. A study conducted by Akhtar et al. (2013) to examine the export competitiveness by employing a set of RCA indices and concluded that Pakistan had a CA and competitive advantage in the horticultural exports. The method of RCA and Johansen cointegration test were employed by Ahmad and Kalim (2014) to gauge the export performance of the clothing and textile sector of Pakistan. The results indicated that the textile sector is significantly contributing to the export performance of Pakistan while these two sectors did not get the advantage of quota elimination policy. Rehman et al. (2015) employed OLS and Johansen's co-integration test to measure the impact of major field crops of Pakistan on the growth of agricultural GDP during 19502015. The findings showed that the output of rice, wheat and cotton has a significant impact on the share of agriculture in GDP. The RCA index was utilized by Abbas and Muhammad (2016) to examine the export competitiveness over Europe and Asia from 2003-2013. The findings illustrated that Pakistan had a higher CA in the low value-added commodities. Waheed and Abbas (2017) investigated the trade competitiveness of Pakistan by employing RCA from 2003-14 and concluded that the agricultural sector had a high CA in cereals, raw cotton, fruits and raw leather. The export potential and competitiveness of Pakistani rice in the international market were examined by Irshad et al. (2018) by utilizing a panel gravity method during 2003-2016. The results elucidated that Pakistan had a high competitive advantage and CA in the rice export in the world. Another study carried out by Javed et al. (2018) to 
measure the competitiveness in the agricultural exports of Pakistan by using the nominal protection coefficient (NPC). The study concluded that Pakistan had a CA in cotton, beef, and vegetables, while competitive disadvantage in basmati, mutton, dairy products and sugar. Lateef et al. (2018) conducted a study to measure the export competitiveness of the agricultural sector of Pakistan by employing RCA method during 2003-2013 and discovered a strong CA of Pakistan in the cotton, rice and tangerines.

\section{Methods and Material}

The study collected the data from the International Trade Center UN-COMTRADE Statistics for cereal exports of Pakistan from 2003-18. It utilized such indices of revealed comparative advantage namely Balassa index (1965), Revealed Symmetric Comparative advantage index (RSCA) (Larsen 1998), Net export index (NEI), Revealed Import Advantage index (RMA), Vollrath index(RCA\#) (1991) and Revealed Trade Advantage index (RTA) to measure the cereal export competitiveness of Pakistan in the global market.

\subsection{Revealed comparative advantage index}

Liesner (1958) was the first who introduced the RCA index which was utilized by Balassa (1965) to measure the competitiveness (Balassa, 1965). The RCA of exports is described as the ratio of exports of a country in a specific product group to its share in total merchandise exports (Balassa and Noland, 1989).

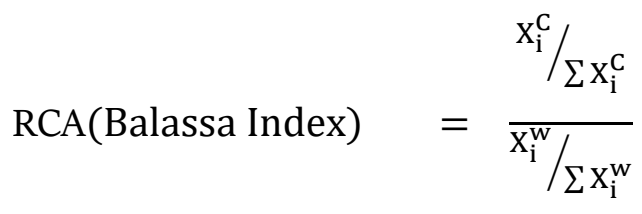

Source; Erkan and Sarıçoban, 2014

Where, $X_{i}^{C}=$ Pakistan's cereal exports, $\sum X_{i}^{C}$ =Pakistan's total exports, $X_{i}^{w}=$ World's cereal exports, $\sum X_{i}^{\mathrm{w}}=$ Total exports of world. To check the power of CA, Balassa index of RCA classified into four classifications. The study also utilized LnRCA to check the comparative advantage of cereal and $\ln R C A>0$ illustrates CA, while $\operatorname{lnRCA}<\mathrm{o}$ indicates comparative disadvantage (Faustino, 2008).

Table 2: Classifications of RCA

\begin{tabular}{|l|l|l|}
\hline Sr. No & Classifications of RCA & Interpretations \\
\hline 1 & $0<$ RCA $\leq 1$ & Indicating no CA \\
\hline 2 & $1<$ RCA $\leq 2$ & Highlights weak CA \\
\hline 3 & $2<$ RCA $\leq 4$ & Describing moderate CA \\
\hline 4 & RCA $>4$ & Showing strong CA \\
\hline
\end{tabular}

Source; Hinloopen, 2001

\subsection{Net Export Index}

Balassa (1965) employed Net export index (NEI) for measuring the competitiveness of the export commodities. This study has also employed this method explained as net exports divided by the sum of exports and imports for a specific manufacturing industry or economy (Balassa and Noland, 1989). NEI method is used to scrutinize whether a country has got specialization in the exports for a specific product group (as net-exporter) or in imports (as net-importer) (Erkan and Sarıcoban, 2014). The absolute value of $|\mathrm{NEI}|$ reveals the share of inter-industry trade relative to the total global trade of the specific product group, and (1-|NEI $\mid$ ) therefore shows intra-industry trade (Vixathep, 2011).

Source; Erkan and Saricoban, 2014

$$
\mathrm{NEI}=\mathrm{X}-\mathrm{M} / \mathrm{X}+\mathrm{M}
$$




\subsection{Vollrath index}

Vollrath (1991) introduced his index to measure the comparative advantage and competitiveness. Further, it eliminates the problem of double-counting in global trade, and Vollrath index is explained as;

Source; Khai et al., 2016

$$
\mathrm{RCA} \#=\frac{\left\{\frac{\mathrm{z}_{\mathrm{ij}}}{\left(\sum_{\mathrm{i}} \mathrm{z}_{\mathrm{ij}}\right)-\mathrm{z}_{\mathrm{ij}}}\right\}}{\left\{\frac{\left(\Sigma_{\mathrm{j}} \mathrm{z}_{\mathrm{ij}}\right)-\mathrm{z}_{\mathrm{ij}}}{\left[\left(\Sigma_{\mathrm{j}} \Sigma_{\mathrm{i}} \mathrm{z}_{\mathrm{ij}}\right)-\left(\Sigma_{\mathrm{j}} \mathrm{z}_{\mathrm{ij}}\right)\right]-\left[\left(\Sigma_{\mathrm{i}} \mathrm{z}_{\mathrm{ij}}\right)-\mathrm{z}_{\mathrm{ij}}\right]}\right\}}
$$

Where, $\mathrm{Z}_{\mathrm{ij}}=$ Pakistan's cereal exports, $\sum_{\mathrm{i}} \mathrm{Z}_{\mathrm{ij}}=$ Pakistan's total exports, $\sum_{\mathrm{j}} \mathrm{Z}_{\mathrm{ij}}=$ World's cereal exports, $\sum_{\mathrm{j}} \sum_{\mathrm{i}} \mathrm{Z}_{\mathrm{ij}}=$ World's total exports.

\subsection{Revealed Symmetric Comparative Advantage}

The current study solves the dilemma of upward biased values of the RCA utilized Larsen index (1998) which adjusted the values of the RCA index in symmetric values. The position of these adjusted RCA values lies between +1 and -1 . Larsen (1998) described his index as RSCA, which is expressed as;

Source; Erkan and Sarıcoban, 2014

$$
\mathrm{RSCA}=\frac{\mathrm{RCA}-1}{\mathrm{RCA}+1}
$$

\subsection{Revealed Import Advantage Index}

The revealed import advantage index (RMA) is described in the same way as the revealed export advantage index (RCA) but involves imports of the economy. The value of RMA less than 1 indicates a competitive advantage, while higher than 1 shows competitive disadvantage in imports.

$$
\mathrm{RMA}=\frac{\mathrm{M}_{\mathrm{i}}^{\mathrm{C}} / \sum \mathrm{M}_{\mathrm{i}}^{\mathrm{C}}}{\mathrm{M}_{\mathrm{i}}^{\mathrm{W}} / \sum \mathrm{M}_{\mathrm{i}}^{\mathrm{w}}}
$$

Source; Akhtar et al., 2013

Where, $\mathrm{M}_{\mathrm{i}}^{\mathrm{C}}=$ Imports of Cereal of Pakistan, $\sum \mathrm{M}_{\mathrm{i}}^{\mathrm{C}}=$ Total imports of Pakistan, $\mathrm{M}_{\mathrm{i}}^{\mathrm{w}}=$ Cereal imports of world, $\sum \mathrm{M}_{\mathrm{i}}^{\mathrm{w}}=$ Total imports of the world

\subsection{Relative Trade Advantage Index}

The Relative Trade Advantage index (RTA) highlights the net trade advantage or a trade disadvantage of an economy. It is measured by taking the difference between the Revealed export advantage index (RCA) and Revealed import advantage (RMA) index.

$$
\mathrm{RTA}=\mathrm{RCA}-\mathrm{RMA}=\frac{\mathrm{X}_{\mathrm{i}}^{\mathrm{C}} / \sum \mathrm{X}_{\mathrm{i}}^{\mathrm{C}}}{\mathrm{X}_{\mathrm{i}}^{\mathrm{W}} / \sum \mathrm{X}_{\mathrm{i}}^{\mathrm{w}}}-\frac{\mathrm{M}_{\mathrm{i}}^{\mathrm{C}} / \sum \mathrm{M}_{\mathrm{i}}^{\mathrm{C}}}{\mathrm{M}_{\mathrm{i}}^{\mathrm{W}} / \sum \mathrm{M}_{\mathrm{i}}^{\mathrm{w}}}
$$

Source; Akhtar et al., 2013 


\subsection{Product Mapping}

The study developed "Products Mapping” by utilizing the NEI and RSCA indices (Widodo, 2009). The cereal sector of Pakistan can be classified into four groups A, B, C and D as described in table 3.

Table 3

\begin{tabular}{|l|l|}
\hline Group; A & Group; B \\
CA & CA \\
Net-exporter country & Net-importer country \\
(RSCA > o and NEI $>$ o) & (RSCA >o and NEI <0) \\
\hline Group ; C & Group; D \\
Comparative Disadvantage & Comparative Disadvantage \\
Net-exporter country & Net-importer country \\
$($ RSCA $<$ o and NEI $>0)$ & $($ RSCA $<$ o and NEI $<0)$ \\
\hline
\end{tabular}

Source: Widodo, 2009

\section{Results and Discussion}

The present study employed different indices of comparative advantage to measure the competitive and comparative advantage in the cereal sector of Pakistan during 2003-18. Figure 1 highlights the trend of different revealed comparative advantage indices of Pakistan's cereal sector from 2003-18. In table 4, the findings of the analysis reveal that Pakistan had a CA in the cereal sector having the RCA values greater than 1 during 2003-18 (Sharif et al.,2015). The findings also illustrate that Pakistan achieved and maintained the higher CA in this sector having RCA index greater than 4 from 2003-18. In addition, the InRCA indicates the CA in above-mentioned sector up to 2018 (Abbas and Waheed, 2017). The results showed that cereal revealed comparative advantage has both an increasing and decreasing trend under analysis. The factors responsible for the decline in the competitiveness are high tax rate, high prices, production cost and shortage of electricity. The deficiency of Research and Development (R\&D) was also one of the major determinants behind the decline in the cereal competitiveness of Pakistan(Irshad et al., 2018).

Table 4 Revealed competitive advantage indicators for Cereals in Pakistan from 2003-2018

\begin{tabular}{|l|l|l|l|l|l|l|l|l|}
\hline Years & RCA & RSCA & LnRCA & RCA\# & RMA & RTA & NEI & $1-$ NEI \\
\hline 2003 & 7.9275 & 0.776 & 2.070 & 8.35 & 0.190 & 7.73 & 0.958 & 0.042 \\
\hline 2004 & 10.112 & 0.820 & 2.314 & 10.73 & 0.402 & 9.71 & 0.895 & 0.105 \\
\hline 2005 & 15.962 & 0.882 & 2.770 & 17.47 & 1.336 & 14.63 & 0.744 & 0.256 \\
\hline 2006 & 16.272 & 0.884 & 2.789 & 17.77 & 0.972 & 15.30 & 0.794 & 0.206 \\
\hline 2007 & 13.296 & 0.860 & 2.587 & 14.45 & 0.576 & 12.72 & 0.836 & 0.164 \\
\hline 2008 & 18.878 & 0.899 & 2.938 & 21.9 & 5.351 & 13.53 & 0.195 & 0.805 \\
\hline 2009 & 16.339 & 0.885 & 2.794 & 18.52 & 1.509 & 14.83 & 0.693 & 0.307 \\
\hline 2010 & 18.97 & 0.900 & 2.943 & 21.67 & 0.324 & 18.65 & 0.938 & 0.062 \\
\hline 2011 & 17.044 & 0.889 & 2.836 & 19.48 & 0.319 & 16.73 & 0.934 & 0.066 \\
\hline 2012 & 12.773 & 0.855 & 2.547 & 14.07 & 0.298 & 12.47 & 0.915 & 0.085 \\
\hline 2013 & 13.318 & 0.860 & 2.589 & 14.73 & 0.780 & 12.54 & 0.807 & 0.193 \\
\hline 2014 & 14.099 & 0.868 & 2.646 & 15.65 & 0.887 & 13.21 & 0.771 & 0.229 \\
\hline 2015 & 13.934 & 0.866 & 2.634 & 15.45 & 0.343 & 13.59 & 0.899 & 0.101 \\
\hline 2016 & 13.852 & 0.865 & 2.628 & 15.28 & 0.492 & 13.36 & 0.843 & 0.157 \\
\hline 2017 & 13.437 & 0.861 & 2.598 & 14.75 & 0.255 & 13.18 & 0.900 & 0.100 \\
\hline 2018 & 17.182 & 0.890 & 2.844 & 19.34 & 0.355 & 16.83 & 0.895 & 0.105 \\
\hline
\end{tabular}


Source; Author's calculations by utilizing ITC data

The RSCA index trend described that Pakistan raised specialization in the export of cereal. The positive values of RSCA highlight the CA in the cereal during the selected period. The Vollrath index (1991) was also employed to measure the competitive advantage in the cereal sector. The Vollrath index (RCA\#) illustrates the competitive advantage in the cereal sector during the above mentioned period (Irshad et al.,2018). The revealed import advantage (RMA) shows that Pakistan had a competitive advantage in the years 2003, 2004, 2006, 2007 and 2010-18, while the competitive disadvantage in the years 2005, 2008 and 2009. The positive RTA index describes that Pakistan had a net CA in this sector (Riaz and Jansen, 2012 and Javed et al., 2018). Pakistan is the net-exporter of cereal sector during analysis. Also, the absolute values of NEI indicate that Pakistan remained the net exporter of the cereal sector throughout the selected period. The absolute values of the net export index NEI|highlight the portion of inter-industry trade in the cereal sector of Pakistan, while 1- NEI/depicts the portion of intraindustry trade. According to the 'Product mapping' cereal sector of Pakistan lies in the group A.

Figure 1 Revealed comparative advantage indices drawn against selected years

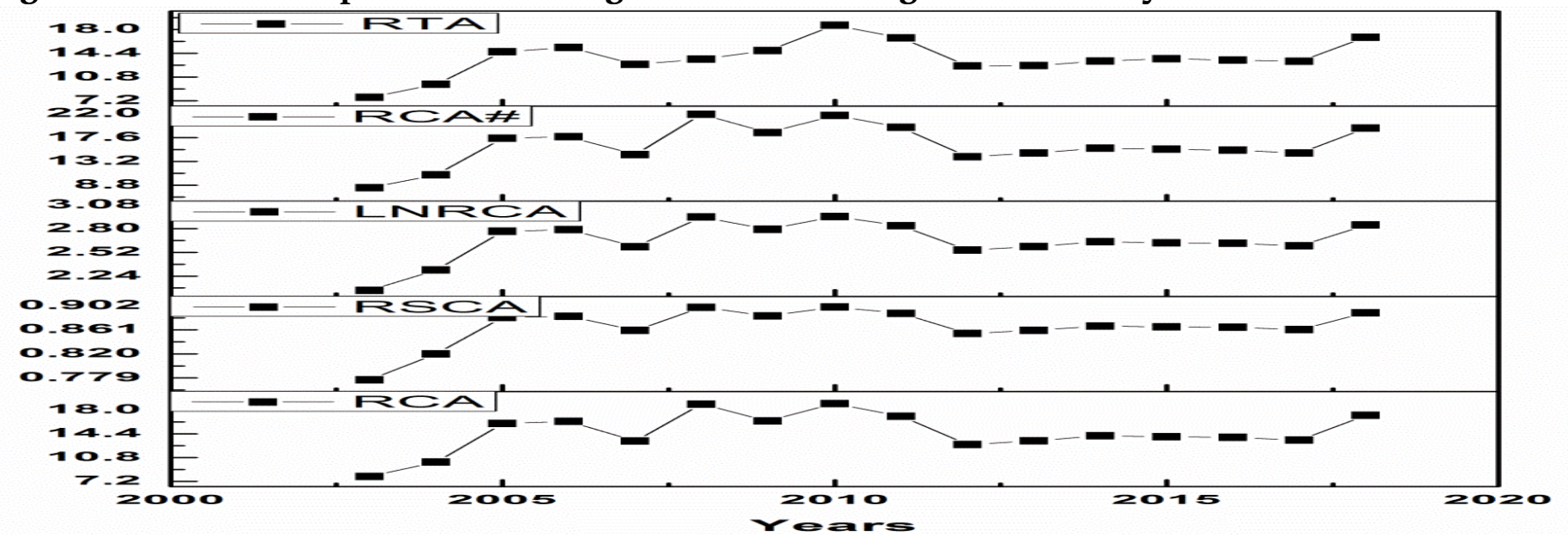

\section{Conclusion}

The current study aims at investigating the cereal export competitiveness of Pakistan in the global market from 2003-2018. The study employed several indices of revealed comparative advantage such as Balassa index (RCA), RCA\#, RSCA, RMA, RTA and Net export index to measure the export competitiveness. The data have been calculated from the International Trade Center for cereal exports of Pakistan. The results of the study highlight that Pakistan had a competitive and comparative advantage in the export of cereal throughout the selected time period. Moreover, the study also observed that Pakistan has a net comparative advantage in this sector. The brand name marketing of Pakistani rice with a special focus on better quality and improved market access can enhance the country's share of the cereal sector in the global market.

\section{References}

Abbas, S., \& Mohammad, S. D. (2016). Pakistan's international competitiveness over Asia and Europe. Pakistan Journal of Commerce and Social Sciences (PJCSS), 10(2), 359-367.

Abbas, S., \& Waheed, A. (2017). Trade competitiveness of Pakistan: evidence from the revealed comparative advantage approach. Competitiveness Review: An International Business Journal, 27(5), 462-475.

Ahmad, N., \& Kalim, R. (2014). Implications of export competitiveness, and performance of Textile and 
Clothing Sector of Pakistan: Pre and post quota analysis. Pakistan Journal of Commerce and Social Sciences (PJCSS), 8(3), 696-714.

Akhtar, W., Akmal, N., Shah, H., Niazi, M. A., \& Tahir, A. (2013). Export competitiveness of Pakistani horticultural products. Pakistan Journal of Agricultural Research, 26(2).

Asif, M. (2013). Climatic change, irrigation water crisis and food security in Pakistan.

Balassa. B. (1965). Trade liberalization and "revealed" comparative advantage. The Manchester School, 33(2), 99-123.

Balassa, B., \& Noland, M. (1989). “'Revealed" Comparative Advantage in Japan and the United States. Journal of International Economic Integration, 8-22.

Bender, S., \& Li, K. W. (2002). The changing trade and revealed comparative advantages of Asian and Latin American manufacture exports. Yale Economic Growth Center Discussion Paper, (843).

Boczar, P., \& Błażejczyk-Majka, L. (2011). Competition for space between cereals and oil crops in terms of its worldwide dynamics. ACTA SCIENTIARUM POLONORUM, 5 .

De Janvry, A. (2010). Agriculture for development: new paradigm and options for success. Agricultural Economics, 41, 17-36.

Erkan, B., \& Sarıçoban, K. (2014). Comparative Analysis of the Competitiveness in the Export of Science-Based Goods Regarding Turkey and the EU+ 13 Countries. International Journal of Business and Social Science, 5(8).

Gonzalez, C. G. (2002). Institutionalizing inequality: the WTO Agreement on Agriculture, food security, and developing countries. Colum. J. Envtl. L., 27, 433.

Hobbs, P. R., Sayre, K., \& Gupta, R. (2007). The role of conservation agriculture in sustainable agriculture. Philosophical Transactions of the Royal Society B: Biological Sciences, 363(1491), 543-555.

Haddad, M. (2000, October). Export competitiveness: where do the Middle East and North Africa region stand?. Economic Research Forum.

Harwood, R. R. (2019). Small farm development: Understanding and improving farming systems in the humid tropics. CRC Press.

Halilbasic, M., Brkic, S., \& Bosic, V. (2015). The Comparative Analysis of Export Competitiveness of exYu Countries. Economic analysis, 48(1-2), 108-129.

Hinloopen,j.(2001).On the empirical distribution of the Balassa index.Reviewed of world economics $.137(1) .131-49$

Irshad, M. S., Xin, Q., \& Arshad, H. (2018). Competitiveness of Pakistani rice in the international market and export potential with the global world: A panel gravity approach. Cogent Economics \& Finance, 6(1), 1486690.

Javed, I., Mustafa, G., Ashfaq, M., Yasmeen, R., Ghafoor, A., Yasin, M., ... \& Imran, M. A. (2018). Competitiveness in agricultural trade of Pakistan with the United Arab Emirates. Pakistan Journal of Agricultural Sciences, 55(3).

Kim, M. (2019). Export Competitiveness of India's Textiles and Clothing Sector in the United States. Economies, 7(2), 47.

Lateef, M., Tong, G., Abdullah, M., Mazhar, N. I., Ahmad, Z., \& Usman, M. R. (2017). Finding impact of Pakistan-China free trade agreement (PCFTA) on agricultural exports of Pakistan-gravity model approach. International Journal of u-and e-Service, Science and Technology, 10(8), 81-90.

Lateef, M., Guangji, T., Riaz, M., Ishaq, M., Abdullah, M., \& Zeeshan, A., (2018). Agricultural Exports Competitiveness of Pakistan in the Global Market.Journal of Northeast Agricultural University (English Edition). June 2018 Vol. 25 No. 2 77-87

Laursen, K. (1998). Revealed Comparative Advantage and the alternatives as Measure of International Specialisation, Danish Research Unit for Industrial Dynamics, DRUID Working Paper No. 98-30, Copenhagen, Denmark. 
Liesner, H. H. (1958). The European common market and British industry. The Economic Journal, 68(270), 302-316.

Mahmood, A. (2000). Export specialization and competitiveness of the Malaysian manufacturing: trends, challenges, and prospects.Fifth Annual Conference on International Trade Education and Research Melbourne. 26 - 27 October. 2000.

Matthews, A., \& Enlarged, E. U. (2006), September). Decoupling and the Green Box: international dimensions of the reinstrumentation of agricultural support. In 93rd EAAE seminar" Impacts of Decoupling and Cross Compliance on Agriculture in the Enlarged EU.

Pfluger, M., \& Tabuchi, T. (2019). Comparative advantage, agglomeration economies and trade costs. Journal of Urban Economics, 109, 1-13.

Rehman, A., Jingdong, L., Shahzad, B., Chandio, A. A., Hussain, I., Nabi, G., \& Iqbal, M. S. (2015). Economic perspectives of major field crops of Pakistan: An empirical study. Pacific Science Review B: Humanities and Social Sciences, 1(3), 145-158.

Riaz, K., \& Jansen, H. G. (2012). Spatial patterns of revealed comparative advantage of Pakistan's agricultural exports. Pakistan Economic and Social Review, 97-120.

Rockström, J., Lannerstad, M., \& Falkenmark, M. (2007). Assessing the water challenge of a new green revolution in developing countries. Proceedings of the National Academy of Sciences, 104(15), 6253-626o.

Sharif, M., Niazi, M. A., Mahar, A. B., \& Jabbar, A. (2015). Study on competitiveness of cereals and their products exports from Pakistan. Journal of Agricultural Research (03681157), 53(3).

Sultana, H., Ali, N., Iqbal, M. M., \& Khan, A. M. (2009). Vulnerability and adaptability of wheat production in different climatic zones of Pakistan under climate change scenarios. Climatic Change, 94(1-2), 123-142. The website assessed https://comtrade.un.org/

Thelwell, D., \& Ritson, C. (2006). The international competitiveness of the UK cereals sector (No. 7362016-50778).

Thorne, F. S. (2005). Analysis of the competitiveness of cereal production in selected EU countries (No. 724-2016-49320).

Tonini, A., \& Cabrera, E. (2011). Opportunities for global rice research in a changing world (No. 22152019-1630).

Vixathep, S. (2011). Trade liberalization and comparative advantage dynamics in Lao PDR. Lao Trade Research Digest, 2(1), 1-33.

Voicilaş, D. M. (2014). Cereal market in Romania-regional competitiveness. In Agrarian Economy and Rural Development-Realities and Perspectives for Romania. 5th Edition of the International Symposium (pp. 94-103). Bucharest: The Research Institute for Agricultural Economy and Rural Development (ICEADR).

Vollrath, T. L. (1991). A theoretical evaluation of alternative trade intensity measures of revealed comparative advantage. Weltwirtschaftliches Archiv,127(2), 265-280.

Widodo, T. (2009). Comparative advantage: theory, empirical measures and case studies. Review of Economic and Business Studies, 4(1), 57-82.

Wise, T. A. (2004). The paradox of agricultural subsidies: measurement issues, agricultural dumping, and policy reform(No. 1434-2016-118850).

Xu, J., Liu, Y., \& Yang, L. (2018). A Comparative Study of the Role of China and India in Sustainable Textile Competition in the US Market under Green Trade Barriers. Sustainability, 10(5), 1348.

Zhou, M. X. (2009). Barley production and consumption. In Genetics and improvement of barley malt quality (pp. 1-17). Springer, Berlin, Heidelberg. 